\title{
Correlation of Vascular Adhesion Molecule in Subjects without Vascular Complication
}

\author{
Geetha Bhaktha ${ }^{1}$, Manjula $\mathrm{B}^{1}$, Rangantha $\mathrm{M}^{2}$, Gurupadappa $\mathrm{K}^{3}$, Parameshwara $\mathrm{S}^{2 *}$
}

${ }^{1}$ Multidisciplinary Research Unit, Shimoga Institute of Medical Science, Shivamogga, Karnataka, India

${ }^{2}$ Department of Cardiology, Mc Gann's teaching District hospital Shivamogga, Karnataka, India

${ }^{3}$ Department of Biochemistry, Shimoga Institute of Medical Science, Shivamogga, Karnataka, India

DOI: $10.36347 /$ sasjm.2020.v06i07.001

| Received: 16.03.2020 | Accepted: 23.03.2020 | Published: 29.07.2020

*Corresponding author: Dr. Parameshwara $\mathrm{S}$

Abstract

Original Research Article

An established independent risk factor for Cardio Vascular Disease (CVD) is diabetes. .Cardiovascular (CV) morbidity is a main burden in patients with type 2 diabetes mellitus (type 2 DM), with endothelial dysfunction as an early indicator of diabetic vascular disease that is linked to the presence of a low-grade vascular inflammation. Since CAM is an index of inflammatory endothelial activation, a assessor of conventional cardiovascular risk factor evaluating it in an early stage would reduce the burden of morbidity and mortality among the DM subjects. Materials and Methods: This is a cross sectional study where in 36 patients with no vascular complication, matched with 33 controls were selected from OPD of Department of General Medicine. The cases where diabetic for at least 1 year. VCAM-1 levels were estimated by commercial kit available from Ray Biotech Pvt. Ltd by ELISA method. Result: Diabetic subjects showed a higher levels of VCAM-1 than the Normal subjects. When correlation beween the two groups were analysed, VCAM-1 showed significant correlation with the duration of diabetes $(\mathrm{p}=.002, \mathrm{r}=.494)$. When genderwise correlation was ploted, it was seen that in diabetic female subjects the difference was significant $(\mathrm{p}=.007$, $\mathrm{r}=.523$ ) with respect to VCAM-1 molecule. Conclusion: Though the clinical manifestation of vascular complication is not identifiable, the simulation for the expression of VCAM-1 molecule is evident. Hence VCAM-1 may be used as an early marker for vascular complications.

Keywords: Diabetes, Cell adhesion molecule, Vascular Cellular Adhesion Molecule.

Copyright @ 2020: This is an open-access article distributed under the terms of the Creative Commons Attribution license which permits unrestricted use, distribution, and reproduction in any medium for non-commercial use (NonCommercial, or CC-BY-NC) provided the original author and source are credited.

\section{INTRODUCTION}

Diabetes is considered as an established risk factor for heart disorders. Also it is understood to be a important cause of death among the diabetic subjects [1]. It is observed that when diabetic subjects attain clinical CVD, chances of their prognosis are less than those without hyperglycemia $[2,3]$. The most common attributable factor for their mortality is endothelial dysfunction. This endothelial dysfunction is nothing but a low-grade vascular inflammation which is more prevalent in lost term hyperglycemic subjects. Subsequently this endothelial dysfunction contributes to the pathogenesis of micro and macrovascular complications like diabetic nephropathy, diabetic neuropathy and diabetic retinopathy will eventually leads to formation of atherosclerotic lesion over decades. In the earlier stages changes in endothelin1(ET-1) in the endothelium occurs through the stimulation of leukocyte adhesion molecules $[4,5]$ thus begins the beginning of the vascular inflammation.
Cellular adhesion molecules (CAMs), are members of selectin family involved in recruitment of leucocytes to the site of inflammation and are constantly expressed on several cell types in normal conditions on the resting endothelium. However these get upregulated throughout the exposure to proinflammatory stimuli as in during atherogenesis [6] hence acts as a biomarker in vascular disease [7, 8]. In diabetic subjects sustained exposure to hyplerglycemia trigger damages to the endothelium because of continuous oxidative stress [9]. Studies have shown that long term exposure to hyperglycemia has found to increase the level of endothelial dysfunction by raising the level of vascular cellular adhesion molecule. Since VCAM can reflect the inflammatory endothelial activation on long term exposure, a assessor of conventional cardiovascular risk factor evaluating it in an early stage would reduce the burden of morbidity and mortality among the DM subjects [10]. Hence estimating the VCAM would target in finding the risk 
assessment of CVD in diabetic subjects who have not developed micro and macro vascular complications.

\section{MATERIALS \& METHODS}

This study involved 36 patients with no vascular complications from OPD of General Medicine from Mc Gann Teaching district hospital, Shimoga.controls were selected based on age sex match. Hence 33 controls were recruited. All participants were unreleated subjects who met the inclusion criteria of the study (Male or Female outpatients aged between 30-65 years, Persons with good control over glycemic levels, History of type 2 diabetes for at least 1 year without any preexisting micro and macro vascular disorder and are on diet control or oral hypoglycemic drugs.) all other cases were excluded. Presene of microalbuminuria was ruled out by estimating MAU in urine. Any value less than $30 \mathrm{mg} / \mathrm{g}$ $\mathrm{Cr}$ was considered to be Normoalbuminuria and was considered as free from diabetic nephropathy. Selfhistory of diabetic neuropathy and diabetic retinopathy was taken. This study was approved by the Institutional Ethical clearance board of our institute.

VCAM-1 levels were estimated by commercial kit available from Ray Biotech Pvt. Ltd by ELISA method. The RayBiotech Human VCAM-1 ELISA kit is an in vitro enzyme-linked immunosorbent assay for the quantitative measurement of human VCAM-1 in serum, plasma, and cell culture supernatants. This assay employs an antibody specific for human VCAM-1 coated on a $96-$ well plate.

\section{RESULTS}

The demographic data of the study population when plotted (Table 1) showed that the diabetic subjects were little elder than the controls. The most of the subjects in the control group were known to be diabetic atleast more than a year. It was observed that in both the gender, the BMI was almost the same along with the other parameters like SBP, DBP.

The mean value of total cholesterol was comparatively high in the diabetic subjects than in the normal study group. Surprisingly female diabetic subjects had a higher level of good cholesterol than the normal female subjects.

It is well depicted that the levels of VCAM among the diabetic subjects was higher than in the normal subjects. Also female subjects had higher levels of VCAM than the males as shown in the fig 1.

Table 2 shows the correlation of all the variables of the study population with VCAM. A positive correlation was seen among all the parameters except HDL, in the general study population which was not statistically significant. Among diabetic subjects with respect to the $\mathrm{HC}$, Weight, DBP, Total Cholesterol and HDL-cholesterol a non- significant correlation was seen. Only duration of the diabetes showed statistically significance $(\mathrm{P}=.002, \mathrm{r}=.494)$.

Further when the study population was classified based on gender, among the females duration of the diabetes showed statistically significance $(\mathrm{P}=.007, \mathrm{r}=.523)$ as shown in table 3. But this correlation was lost among the males as shown in table 4.

Table-1: Demographic data of the study population

\begin{tabular}{|l|r|r|r|r|}
\hline & Male Diabetic & Male Normal & \multicolumn{1}{l|}{$\begin{array}{l}\text { Female } \\
\text { Diabetic }\end{array}$} & Female Normal \\
\hline Age (years) & $44.90 \pm 6.00$ & $39.5 \pm 6.76$ & $45.96 \pm 6.88$ & $40.11 \pm 6.50$ \\
\hline $\begin{array}{l}\text { Diabetes Since } \\
\text { (months) }\end{array}$ & $23.81 \pm 15.24$ & NIL & $23.36 \pm 15.95$ & NIL \\
\hline HC $(\mathrm{Cms})$ & $94.27 \pm 6.46$ & $101.12 \pm 11.15$ & $98.72 \pm 7.59$ & $95.17 \pm 11.18$ \\
\hline WC $(\mathrm{Cms})$ & $92.09 \pm 9.25$ & $96.68 \pm 30.71$ & $95.56 \pm 5.82$ & $97.88 \pm 9.82$ \\
\hline Ht (Cms) & $158.36 \pm 13.82$ & $159.5 \pm 10.05$ & $144.48 \pm 6.35$ & $150.76 \pm 7.44$ \\
\hline Wt (Kgs) & $67.45 \pm 10.60$ & $73.12 \pm 15.05$ & $60.63 \pm 7.26$ & $62.88 \pm 13.64$ \\
\hline BMI & $27.13 \pm 4.49$ & $28.68 \pm 5.21$ & $28.98 \pm 2.32$ & $27.58 \pm 5.06$ \\
\hline SBP(mm of Hg) & $111.81 \pm 18.34$ & $123.5 \pm 9.72$ & $124.88 \pm 22.24$ & $114.17 \pm 8.67$ \\
\hline DBP(mm of Hg) & $80.90 \pm 12.21$ & $78.25 \pm 7.79$ & $77.96 \pm 12.48$ & $76.58 \pm 5.03$ \\
\hline Chol (mg/ dl) & $206.27 \pm 31.87$ & $165.06 \pm 41.07$ & $215.52 \pm 36.68$ & $170.11 \pm 41.94$ \\
\hline HDL (mg/dl) & $54 \pm 14.56$ & $43 \pm 11.00$ & $59.68 \pm 11.56$ & $53.82 \pm 10.04$ \\
\hline
\end{tabular}




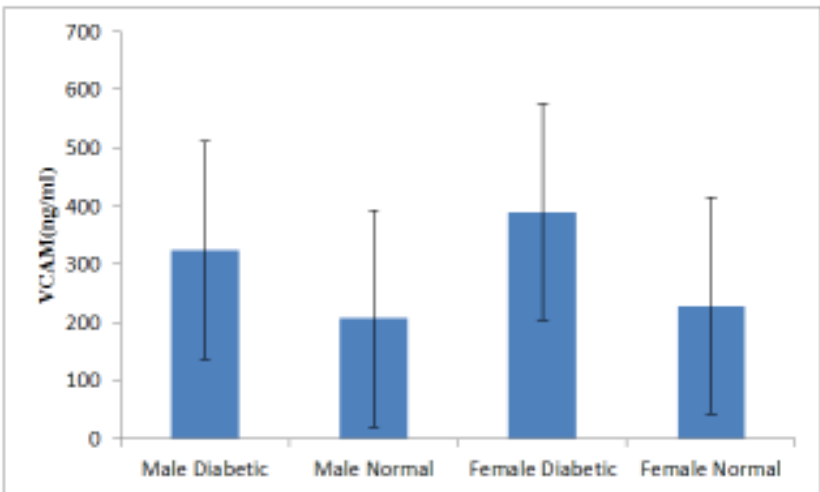

Fig-1: Levels of VCAM of the study population

Table-2: Correlation of Total study population

\begin{tabular}{|c|c|c|c|c|}
\hline \multirow[t]{2}{*}{ variable } & \multicolumn{2}{|c|}{$\begin{array}{c}\text { Normal(VCAM) } \\
(n=33)\end{array}$} & \multicolumn{2}{|c|}{$\begin{array}{c}\text { Diabetic(VCAM) } \\
(n=36)\end{array}$} \\
\hline & $* \mathbf{P}$ & $\mathbf{r}$ & $\mathbf{P}$ & $\mathbf{r}$ \\
\hline $\mathrm{HC}(\mathrm{Cms})$ & .997 & .000 & .164 & -.237 \\
\hline $\mathrm{WC}(\mathrm{Cms})$ & .379 & .158 & .759 & .053 \\
\hline $\mathrm{Ht}(\mathrm{Cms})$ & .410 & -.148 & .179 & -.229 \\
\hline Wt (Kgs) & .555 & .107 & .312 & -.173 \\
\hline BMI & .146 & .259 & .689 & .069 \\
\hline SBP & .951 & .011 & .736 & -.058 \\
\hline DBP & .764 & -.054 & .818 & -.040 \\
\hline Cholesterol(mg/dl) & .733 & .062 & .968 & -.007 \\
\hline HDL (mg/dl) & .227 & -.216 & .619 & -.086 \\
\hline Duration of diabetes & & & .002 & $.494 * *$ \\
\hline
\end{tabular}

Table-3: Correlation of female Total study population

\begin{tabular}{|c|c|c|c|c|}
\hline \multirow[t]{2}{*}{ variable } & \multicolumn{2}{|c|}{$\begin{array}{c}\text { Normal(VCAM) } \\
(\mathrm{n}=17)\end{array}$} & \multicolumn{2}{|c|}{$\begin{array}{c}\text { Diabetic(VCAM) } \\
(\mathrm{n}=25)\end{array}$} \\
\hline & $\mathbf{P}$ & $\mathbf{r}$ & $\mathbf{P}$ & $\mathbf{r}$ \\
\hline $\mathrm{HC}(\mathrm{Cms})$ & .726 & -.092 & .180 & -.277 \\
\hline $\mathrm{WC}(\mathrm{Cms})$ & .966 & -.011 & .699 & .081 \\
\hline $\mathrm{Ht}(\mathrm{Cms})$ & .205 & -.324 & .937 & -.017 \\
\hline Wt (Kgs) & .965 & .011 & .708 & -.079 \\
\hline BMI & .448 & .197 & .684 & -.086 \\
\hline SBP & .998 & .000 & .955 & .012 \\
\hline DBP & .072 & -.447 & .663 & .092. \\
\hline Cholesterol(mg/dl) & .936 & .021 & .990 & -.003 \\
\hline HDL (mg/dl) & .185 & -.338 & .389 & -.180 \\
\hline Duration of diabetes & & & .007 & $.523 * *$ \\
\hline 0.01 & & & can & \\
\hline
\end{tabular}

Table-4: Correlation of male Total study population

\begin{tabular}{|c|c|c|c|c|}
\hline \multirow[t]{2}{*}{ Variable } & \multicolumn{2}{|c|}{$\begin{array}{c}\text { Normal(VCAM) } \\
(\mathrm{n}=16)\end{array}$} & \multicolumn{2}{|c|}{$\begin{array}{c}\text { Diabetic(VCAM) } \\
(n=11)\end{array}$} \\
\hline & $\mathbf{P}$ & $\mathbf{r}$ & $\mathbf{P}$ & $\mathbf{r}$ \\
\hline $\mathrm{HC}(\mathrm{Cms})$ & .514 & .176 & .362 & -.305 \\
\hline $\mathrm{WC}(\mathrm{Cms})$ & .278 & .289 & .811 & -.082 \\
\hline $\mathrm{Ht}(\mathrm{Cms})$ & .831 & .058 & .068 & -.568 \\
\hline Wt (Kgs) & .242 & .310 & .343 & -.316 \\
\hline BMI & .151 & .376 & .417 & .273 \\
\hline SBP & .682 & .111 & .087 & -.539 \\
\hline DBP & .225 & .321 & .174 & -.442 \\
\hline Cholesterol(mg/dl) & .677 & .113 & .781 & -.095 \\
\hline HDL (mg/dl) & .420 & -.217 & .876 & .053 \\
\hline Duration of diabetes & & & .184 & .432 \\
\hline \multicolumn{5}{|c|}{ **. Correlation is significant at the } \\
\hline
\end{tabular}




\section{DISCUSSION}

A substaintiated fact about diabetes mellitus is that it isassociated with a greater risk of myocardial infarction, stroke, and peripheral artery disease.Hyperglycemia is an important risk factor for cardiovascular disease due to production of free radicals. These free radicals increase the expression of adhesion molecules, hence contributing to the development of vascular complication [9, 11]. In our study population the diabetic group had a higher value of VCAM than the normal study population. This is agreeing with the studies conducted by Hadi et al.

It is studied that there exists non- enzymatic coupling of glucose molecules with the lysine of the protein. This glycated protein is believed to have a strong adherening capacity to immunoglobulin or to the mechanism which activate the process of inflammation. Hence this causes the damage to the vascular endothelium $[12,13]$. Also other known mechanism of causing vascular remodeling is over synthesis of reactive oxygen species, which are responsible for lipid abnormalities along with the release of proinflammatory cytokines and stimulation of renninangiotensisn system [14].

When gender wise levels of VCAM were tablulated, it was observed that female had a higher level of VCAM than the males as shown in Figure 1. But this was contradicted by $\mathrm{Ab}$ et al where they reported a higher levels in females [15] this may be partly be explained on the basis that menopausal state and the treatment taken during post-menopausal like hormone replacement therapy influence the level of VCAM. In our study most of the female had not reached the menopausal state and hence the discrepancy. Also study by McCrohon et al. has shown that androgen exposure increases human monocyte adhesion to vascular endothelium and endothelial cell expression of vascular cell adhesion molecule is apparent, this may explain some protection among the women in premenopausal state in developing CVD [16].

Several studies have supported the idea of influence of lipid levels and statin therapy on expression of CAM. Studies have also shown that higher levels of cholesterol, LDL are known to increase the VCAM levels [17] [18]. But observational studies did not associate with the levels of cholesterol or LDL in three large studies which is similar to our observation. Also we found negative associations with HDL (table 2) which also agree with two studies [19, 20].

Our study showed a significant correlation between VCAM and duration of diabetes (table 2). Our study diabetic subjects had hyperglycemic state since 23 months and we assume that this duration was sufficient to reflect the expression of VCAM levels. Further when gender wise correlation was tabulated, we still found significant correlation among the diabetic female subjects and no correlation was found in the diabetic male subjects (table $3 \& 4$ ). These changes may be due to hormonal effects [16].

A well-known fact is that expression of adhesion molecules correlate with BMI,in fact excess of adipose tissue exert a low grade of inflammation hence the effect [21]. But in our study there was no significant correlation between BMI or WC or HC and VCAM levels (table 3\&4).

\section{CONCLUSION}

Our group showed significant correlation only between duration of diabetes and VCAM. Which may explain that though the clinical manifestation of vascular complication are not nor apperant, the stimation for the expression mere by exposure of hyperglycemic state is evident. This reveals the fact that interaction between VCAM synthesis and its role with respect to its concentration in the blood may elucidate the discrepancies among the mechanism and the clinical findings.

\section{ACKNOWLEDGEMENTS}

Authors acknowledge the Department of Health Research, New Delhi, India for providing the facilities at Multidisciplinary Research Unit for the study. We are grateful to participants who took part in the stidy. Also thank Mrs. Revathy, Biostatician for helping through the statistics.

\section{DECLARATIONS}

Funding: This work was supported by Multidisciplinary Research Unit, Department of Health Research, New Delhi,

Ethical approval: Institutional Ethics Committee, Shimoga Institute of Medical Science, Shivamogga. Ref. No.: SIMS/IEC/212/2015-16

\section{REFERENCE}

1. Geiss LS, Herman WH, Smith PJ, National Diabetes Data Group. Diabetes in America. Bethesda, Md: National Institutes of Health, National Institute of Diabetes and Digestive and Kidney Diseases.1995;233-257.

2. Am Coll J. Stone PH, Muller JE, Hartwell T, York BJ, Rutherford JD, Parker CB, Turi ZG, Strauss HW, Willerson JT, Robertson T, et al. The MILIS Study Group. The effect of diabetes mellitus on prognosis and serial left ventricular function after acute myocardial infation: contribution of both coronary disease and diastolic left ventricular dysfunction to the adverse prognosis. J Am Coll Cardiol. 1989;14:49-57. 
3. Singer DE, Moulton AW, Nathan DM. Diabetic myocardial infarction: interaction of diabetes with other preinfarction risk factors. Diabetes. 1989;38:350-357.

4. Tostes R. C. A. and.Muscar'aM. N. Endothelin receptor antagonists: another potential alternative for cardiovascular diseases," Current Drug Targets - Cardiovascular and Haematological Disorders, 2005;5(4): 287-301.

5. Insel P. A., Kornfeld S., Majerus P.W., et al., "Blasts from the past," Journal of Clinical Investigation, 2004;114( 8):1017- 1033,.

6. Guray U., Erbay A.R., Guray Y., Yilmaz M.B., Boyaci A.A., Sasmaz H., et al. (2004) Levels of soluble adhesion molecules in various clinical presentations of coronary atherosclerosis. Int $\mathbf{J}$ Cardiol 96:235-240.

7. Ley K., Huo Y. VCAM-1 is critical in atherosclerosis. J Clin Invest. 2001;107:12091210 .

8. M. Meydani, "Soluble adhesion molecules: surrogate markers of cardiovascular disease?" Nutrition Reviews. 2003;61(2):63-68.

9. G. Dav`1, A. Falco, and C. Patrono, "Lipid peroxidation in diabetesmellitus," Antioxidants and Redox Signaling., 2005;7(1-2):256-268.

10. Esposito C, Fasoli G, Plati AR, Bellotti N, Conte $\mathrm{MM}$, Cornacchia $\mathrm{F}$ et al. Long-term exposure to high glucose upregulates VCAM-induced endothelial cell adhesiveness to PBMC. Kidney Int. 2001; 59: 1842-1849.

11. Seckin D, Ilhan N, Ilhan N, Ertugrul S, 2006 Glycaemic control, markers of endothelial cell activation and oxidative stress in children with type 1 diabetes mellitus. Diabetes Res Clin Pract 73: 191-197.

12. Hadi, A.R., Suwaidi, J. Endothelial dysfunction in diabetes mellitus. Vasc. Health Risk Manag. 2007;3(6):853- 876.

13. Szmit, S., Opolski, G. Diabetic microangiopathya current look at the pathogenesis and the clinical implications for cardiovascular diseases. Przegl. Kardiodiab. 2006;1(1):27-34 (in Polish)..

14. Żukowska-Szczechowska, E., Wystrychowski, G. Diabetic nephropathy and cardiovascular risk. Przegl. Kardiodiab.2007;2(4):209-213 (in Polish).

15. Abe Y, El-Masri B, Kimball KT, Pownall H, Reilly $\mathrm{CF}$, Osmundsen $\mathrm{K}$ et al. Soluble cell adhesion molecules in hypertriglyceridemia and potential significance on monocyte adhesion. Arterioscler Thromb Vasc Biol. 1998; 18: 723-31.

16. McCrohon JA, Jessup W, Handelsman DJ, Celermajer DS. Androgen exposure increases human monocyte adhesion to vascular endothelium and endothelial cell expression of vascular cell adhesion molecule-1. Circulation 1999; 99: $2317-$ 22.

17. Zhu Y, Liao HL, Lin JH, Verna L, Stemerman MB. Low-density lipoprotein augments interleukin-1induced vascular adhesion molecule expression in human endothelial cells. Atherosclerosis. 1999; 144: 357-65.

18. Scalia R, Appel JZ, Lefer AM. Leukocyteendothelium interaction during the early stages of hypercholesterolemia in the rabbit: role of $\mathrm{P}$ Selectin, ICAM-1, and VCAM-1. Arterioscler Thromb Vasc Biol. 1998;18:1093-100.

19. Rohde LE, Hennekens CH, Ridker PM. Crosssectional study of soluble intercellular adhesion molecule-1 and cardiovascular risk factors in apparently healthy men. Arterioscler Thromb Vasc Biol. 1999;19:1595-1599.

20. Rohde LE, Lee RT, Rivero J, Jamacochian M, Arroyo LH, Briggs W. Circulating cell adhesion molecules are correlated with ultrasound-based assessment of carotid atherosclerosis. Arterioscler Thromb Vasc Biol. 1998;18:1765-1770.

21. Targher G, Bonadonna RC, Alberiche M, Zenere MB, Muggeo M, Bonora E. Relation between soluble adhesion molecules and insulin sensitivity in type 2 diabetic individuals: role of adipose tissue. Diabetes Care. 2001; 24: 1961-1966. 